\title{
Structural and Functional Changes in Bosnian Family - Disappearance of the "Sofra"
}

\author{
Amel Alić \\ University of Zenica
}

\begin{abstract}
The 'sofra' and 'me'edeba' are places where not only physiological needs of food consumption which are necessary for physical life are fulfilled, but they are also places where we prepare on fundamental, intellectual, emotional and social levels for participation in the society, adoption of basic knowledge about ways to satisfy own and others' needs for safety, belonging, recognition, love, (Self) respect, and living of aesthetic and intellectual values. Before we sit at the 'sofra', we participate in serving of the food, and we learn to listen to and look at each other, to educate all senses by exchanging impressions and opinions about tastes. If all meanings of 'sofra' and 'me'edeba' are satisfied, we always happily go back to that place, but we also know how to transfer that knowledge to the next generation. Therefore, we learn to adopt culture through enculturation processes. The most explicit changes in dimension of adaptability and cohesion suggest that Bosnian family, besides social, economy, and political changes, passes through unprecedented and unique transformation, which could be connected to far more complex cultural changes - what we assume to be - transformation of normative / relational collectivism and individualism, increased migrations, different / changed role of religion, and a new paradigm of identity definition. In that sense, this article represents an attempt to determine in what way different custom, forms and functions of Bosnian family, above all, the dominant structure and functions, changes throughout the past three decades.
\end{abstract}

Keywords: Bosnian family, tradition, family changes, the concept of the "sofra"

\section{Introduction}

The word 'tradition' has old linguistic roots. The English word originates from the Latin word 'tradere', which meant 'to transfer' or to 'entrust something to someone for safekeeping.' 'Tradere' was originally used in the context of Roman law, more specifically of inheritance laws. Property ownership which was transferred from one generation to another was given away with confidence - heirs were to protect it and take care of it (Giddens, 2005). The term 'tradition' is a product of modernity and it 
has been used in Europe for the past 200 years; there was no need to use it earlier, considering that people lived it, and that it surrounded them everywhere. It was popularised by enlighteners because they were enchanted by everything that was new, and the enchantment made them identify tradition with dogma and ignorance.

In the Arabic language, the term turas (تراث) is most commonly used for tradition, especially in the sense of Islamic tradition (التراث السلامي), whereas the term taklid (تقليد) refers more to imitation, (blind) following, following one's footsteps. Interestingly, in that sense, the same root is also contained in words mukalled (مقلد), which means the one who follows somebody (e.g. madhhab), and kalladetun (قلادة) which means necklace, existence of a mutual connection and mutually correlated elements. What is blindly followed nowadays in contemporary societies?

According to Anthony Giddens (2005), the contemporary civilisation and transition to industrial and post-industrial societies represent a man's transition from the era of external risk to the era of manufactured risk, while the intention of enlightenment was to destroy the authority of tradition. This applies to societies that can be described as completely detached from nature. Following the accelerated cultural changes, nowadays we can conclude with great certainty that a tradition which loses its contents and becomes commercialized, in the hands of the heritage industry, becomes either heritage or kitsch, and heritage is tradition repackaged into a spectacle. Transfer of values from generation to generation is decreasing, and there is an increasing level of cultural recoding, especially of 'small' and 'inferior' cultures, the cultures that are distant from the centre of today's global nucleus. What does this mean?

Key changes that occurred globally can be explained through Anthony Giddens's ideas of the character of living in detraditionalized societies. Some of these changes imply that, in detraditionalized societies, the following is increasingly happening: Increase of produced risks, unlike former natural risks; production of coercions and addictions; changed definition of reproduction, sexuality and intimacy; moved position and definition of limits (physical, emotional, behaviours, opinions); life in non-nature; jeopardized culture of leisure and relaxation; and fundamental breakup between modern and post-modern family.

Almost without an exception, every today's culture could be analysed from the aspect of cultural reprogramming and de-traditionalization of 'cultural or developmental niché'. All meanings derived from the concept of 'cultural niché' are inseparable from nature. However, there is less and less nature in our lives, which undermines certain meanings of culture that imply that culture is a bridge between nature and the spirit. All of this was reflected in science as well, so one can speak of a simultaneous crisis of postmodern knowledge (Bajramović, 2010). These processes are directly reflected in the concept of health, diet, exposure to stressors and search for the meaning of a man 
who lives in contemporary and, as Anthony Giddens (2007) would characterize it, detraditionalized societies.

\section{The Concept of "Cultural Niché"}

What determines the cultural model of bringing up and of typical family organization of life on the basic level is strongly dependent on characteristics of the environment as well. The importance of interaction of the environment and the way of everyday functioning of the family became the subject of serious consideration in midtwentieth century, when the concept of ecological niché was introduced - as a sum of resources used within certain environment. Namely, different people can exploit different ecological nichés within the same environment, and the concept of 'cultural niché' is derived from bio-ecological observation of one's life habitus. According to Çiğdem Kağıtçıbaşı, there are three development components of a cultural niché surrounding a child: eco-cultural context, features of parental ethno territory, and characteristics of educators in that culture that are determined by ethno territories (Kağıtçıbaşı, 2007). Drew Westen (1999) mentions one of the meanings of the ecological niché using the example of a correlation between the ruling type of economy and social relations that dominate in a culture. Societies that celebrate wealth, possession and power in the context of own cultural niché encourage individuals to develop properties that will enable them to achieve the possession ideal themselves. On the other hand, some cultures derived from the values such as modesty and abstinence as ideals of decency the norms that even prescribe social punishment for excessive piling up of fortunes above the amount of material goods needed for life (or proper subsistence, survival) as determined by that culture and belief.

Such different understanding of possession within the ecological niché of a culture results in completely different socialization and education objectives that strive to develop properties that are viewed as ideal and that lead to the fulfilment of humanity - the main objectives of existence. A change of a cultural model most frequently follows the opposite direction: from customary harmonization with nature - towards conquering the nature; from the value of giving - towards possession... As stated above, in traditional societies (within the ecological and cultural nichés), stability of social position and related roles influenced the stability of identity and the view of oneself as opposed to others. In traditional societies, humans lived in stable and clearly defined identities and roles, respected the nature and waited for the fruit to mature, thereby preparing to respect the final product which was ready for the dining table, for instance; therefore, all risks were completely natural. Introduction of the new comprehension of risk - manufactured risk - is closely related to the insurance flood, and insurance is justified if we believe that humans determine the future. We witness the detachment from nature on our dining tables, menus, in bosnian culture - 'sofra' (derived from Arabic language), and then, through family and the increasingly 
dynamic life, everything we consumed as material and spiritual food is manifested through our behaviour. And this behaviour irresistibly reminds of the everyday 'real life mess' (Bauman, 1991, after: Chaney, 2003) in large cities: it is aggressive, fast, overwhelming, egotistical, focused on achievement and possession...

This is a summarized description of societies that can be described as completely detached from nature. The detachment from nature despiritualized contemporary man through the despiritualized science as well, and we uncritically adopt understanding of the health concept from magazines and websites dealing with health and 'beauty', instructions for bringing up children from summarized popular texts that offer instant solutions based on the 'three in one' principle, and skills for coping with stress from experts on duty who summarize the whole life philosophy in five to ten steps that widely open the door to happiness and optimism, giving us amnesty from the process, and too often from the responsibility which implies spiritual inventory of our everyday life. During all this time, we have less and less time for each other. Particularly for a joint dining table / sofra. Therefore, we have less and less joint moments filled with meaning and symbolic contents.

\section{Methodology and researches useful for monitoring familial changes}

During the past decades, theories of family changes and theories of family modernization approached from different angles the research of the family transformation phenomenon in contemporary societies. Particularly interesting is the research of changes that have overtaken societies marked as those located on the 'periphery of global cultural nucleus', which experienced dramatic transformations of structure, organization and of all forms of family functionality due to acceptance of numerous social reforms imposed from the (geographical, political and economic) West. The research of family changes is important because culture can be understood through understanding of the family structure and organizations, and they were a special subject of research of numerous social disciplines.

Since in the paper of this format we do not have enough space for broader elaboration of all the most important concepts important for this analysis, we will emphasize only a few the most significant ones here. Thus, for instance, Jullian H. Steward (1955) who is deemed one of the precursors of ecological anthropology, presents the thesis that the environment and technology have a decisive importance for the definition of social organizational culture, and that they are directly related to the development and changes of culture, by which he lays the foundations of what is nowadays called ecological anthropology. Influences of ecological factors were researched within regional comparisons and regional traditions, and Alan Barnard (2000) differentiates three types of comparison in anthropology: illustrative, global and controlled (which includes regional comparison). Multinational comparative research presents a search for typical descriptions of different cultures and joint properties and value orientations of members of those cultures, considering national dimensions of 
culture. One of the most complete research of features of national dimensions of cultures within global comparisons is the one offered by Geert Hofstede $(2001,2005)$ who subsequently expanded the understanding of national dimensions of cultures to different standards of everyday behaviour and functioning in family bringing up, school, and society in general. Applying the correlation and factor analysis, Hofstede has managed to collect and compare results for almost 90 cultures, and talking about features of cultures based on research he performed since the late 60es to date, Hofstede presents the thesis that all cultures can be placed on bipolar scales: Power Distance (high and low), Uncertainty Avoidance, Individualism versus Collectivism, Masculinity versus Femininity values and Long-term versus Short-term Oriented Cultures.

A significant contribution to understanding of the characteristics of persons from different cultures was offered by the Israeli psychologist Shalom Schwartz (2007). By culture he implies a wide spectrum of meanings, beliefs, practices, symbols, norms and values that prevail among members of a society. A dominant value in a society can be the most important feature of that culture (Hofstede, 2001, 2005; Schwartz, 2007). When considering the cultural values, the author starts from three universal requirements that every culture strives to fulfil: Defining individual's attitude towards the society; Maintaining of the society; and defining the society's attitude towards natural environment. Schwartz believes that societies approach these requirements differently, which results in the establishment of a common group of main prejudices and beliefs about preferable state of affairs or preferable behaviour of individuals in every society. Based on research of 57 cultures, Schwartz et al. singled out seven foundational value dimensions, and the theory of cultural orientations which is developed by Schwartz classifies cultural responses to the three key issues facing all societies to three bipolar dimensions: embeddedness versus autonomy (intellectual and affective), hierarchy versus egalitarianism, and mastery versus harmony.

The next large study of this kind is the one offered by a group of authors in the book: Culture, Leadership and Organizations - The GLOBE Study of 62 Societies published in 2004 (House et al, 2004). In the GLOBE study, authors grouped and classified cultures in view of different measures of cultural values. Based on the extensive research of cultural values that includes 62 societies, the GLOBE (Global Leadership and Organizational Behaviour Effectiveness) study classifies cultures to ten clusters considering their climate and regional characteristics. These clusters were developed based on inclinations of countries to similar or identical value orientations and, according to authors of this study, there are nine such inclinations: institutional collectivism, in-group collectivism, power distance, uncertainty avoidance, gender egalitarianism, assertiveness, humane orientation, future orientation, and performance orientation. 
As a reaction to methodological deficiencies with regard to laboratory-experimental results of research, and especially the approaches that focused on the linear causality in understanding the development of individuals, one of the most significant concepts from the second half of the 20th century arose - the one offered by Urie Bronfenbrenner within a cross-cultural project entitled Ecology of Human Development, which arose from the general system theory (Bronfenbrenner, 1997).

Bronfenbrenner establishes the concept of a developed system of eco-circles which characterize the position of every person in mutual interaction with others, exposed to different influences, with the person and their family in the middle. Urie Bronfenbrenner observes the functional inter-dependence which continuously exists between living organisms and the natural environment, and introduces a series of unavoidable variables in the construct of systemic causality, which recognize the cultural context of a child and of every individual.

The eighties and nineties of the last century can be described as the decades of individualism - collectivism. According to Çiğdem Kağıtçıbaşı (2007), a fuller understanding of the oppositeness of individualism and collectivism is not possible without an analysis of normative - relational categories within these dimensions. Normative individualism - collectivism relates to social norms, values, conventions (social, generally accepted agreements) and rules. In both dimensions, normativity describes to what extent an individual subordinates their individual interests or supports them, or submits them to serve group or social interests. Self-orientation implies relational dimension of individualism - collectivism, shedding light on the type and quality of relations that an individual establishes with others. Normative collectivism emphasizes interests of a group or team that the individual serves, which always have the priority. On the other hand, normative individualism supports and encourages individual interests, needs, rights and priorities (Kağıtçıbaşı, 2007). This is why 'normative' serves to describe dominant rules and values, and 'relational' serves to describe relations that are established within family in a culture.

We can use all listed researches within regional and global comparisons for an analysis of cultural recoding that the Bosnian-Herzegovinian society undergoes.

\section{Changes in Bosnian familial structure and functionality}

The attempt to verify previous theses through research can be found in the extensive study of Value of Children Study (Kağıtçıbaşı, 2007), which was performed in two occasions: the first study during 1970, and the second study, which compared the effects of social changes that affected family, during 2000 . This study is important also because it enables monitoring of changes that have affected Bosnian-Herzegovinian society and family as well, within the concept of global and regional comparisons. The study included 20,000 respondents, mostly parents, mothers in reproductive age in Korea, the Philippines, Singapore, Taiwan, Thailand, Turkey, Indonesia, United States and West Germany. 
According to Kağıtçıbaşı, the study shows that economic values are in a high correlation with fertility, son preference is highly correlated to societies dominated by collectivism and care for elderly parents (given that the son is in charge of providing economic support to parents, whereas daughters marry and join husband's family), and that life in the city significantly affects all three value groups, considering that life in the city is expensive, and that children are an additional 'expense', even in dominantly collectivist cultures. Comparison between results of the two studies points to dramatic changes in the observed societies. Whereas in Turkey, for example, the utilitarian value of son preference was very strong during the seventies, and thirty years later, under the influence of urbanization, industrialization, and migration of population from rural to urban areas, the utilitarian values changed with time in favour of daughter preference. Namely, in the changed life circumstances, parents are clearly much more supported both economically and emotionally by daughters, which can be attributed to new types of family organization that was developed under the influence of all aforementioned social changes. Daughters' share in financial support to family and parents has increased, not only because of the way of dominant family functioning, but also due to the fact that the women's education and employment rates have been on the rise. At the same time, the percentage of psychological values has increased, considering lower child birth rates than in the past, and parents are facing new social expectations in terms of expressing satisfaction, pride, love, and finding more time in qualitative and quantitative terms for joint activities that parents provide to their children and receive from their children, and all these changes were strongly influenced by changed conditions of life organization as well.

These changes have been present in $\mathrm{BiH}$ society for a long time, too. The research we performed in 2017 (Pašalić-Kreso, Alić, 2017) on a sample of elementary school children established a substantial increase of permissiveness in parental behaviour. In this research, children described their parents as highly emotional, and very lowcontrolling, while descriptions in previous researches were the opposite - children mostly described their parents as highly-controlling, high controls were constant and expected, and this strong control pointed to different outcomes in terms of low or high level of emotionality. Obviously, our family changes very dynamically and quickly, and moves towards the increasing autonomy of its members. Another research (Alić, Cerić, Habibović, 2018a) of students' lifestyles shows that hedonism is the most preferred style $(26.6 \%)$, and this lifestyle is equally lived by both male $(23.7 \%)$ and female respondents $(27.6 \%)$. It is interesting to note that more than one-fourth of students currently live a hedonistic lifestyle, which points to the dominant concept of youth, preferable state of affairs, but also to value orientations of youth that dominate in our society on individual and collective levels within the youth subculture. The very low preference of family-sentimental lifestyle points to the conclusion that family here experiences an unimaginable crisis. Official statistics show that young people increasingly delay marriage, they become financially independent from parents at an 
older age, and divorce rate has visibly increased. In the past decades, familial structure has transformed from hierarchical and multi-generational organization to dominantly nuclear organization, and due to increased divorce rate and remarrying of former spouses, the number of aggregated, reconstituted and blended families has been on the rise.

Our research performed on a sample of 457 students of the University of Zenica and University of Sarajevo (Alić, Cerić, Habibović, 2018b) shows that optimism correlates with higher level of empathy, intercultural sensitivity, and preference of the following lifestyles: religious-traditional, family-sentimental, cognitive style, hedonistic orientation and utilitarian style. Variables of higher assessment of father's and mother's emotionality proved to be important for the higher level of optimism. Favourable emotional climate in the family proved to be an important factor for development of a mature and stable personality, and such individuals have the potential to develop new, emotionally literate generations. In a society like BosnianHerzegovinian, the importance of fostering a functional family proved to be evidently important for a higher level of optimism.

All these changes, be it uncontrolled or planned, eventually affected the dominant type of family organization in today's contemporary societies. Namely, according to Çiğdem Kağıtçıbaşı (2007), all forms and family types of functioning and organization could be presented in four ways (Figure 1):

High level of connection and heteronomy (dependence),

High level of connection and autonomy (preparation for independence),

High level of separation and autonomy (preparation for independence), and

High level of separation and heteronomy (dependence).

Figure 1. Agency, Interpersonal Distance and the Type of Selves and Parenting in Cultural Context (adapted according to: Kağıtçıbaşı, 2007:186) 


\begin{tabular}{|c|c|c|}
\hline & \multicolumn{2}{|c|}{$\begin{array}{l}\text { AGENCY } \\
\text { Autonomy }\end{array}$} \\
\hline & Family model of independence & $\begin{array}{l}\text { Family model of psychological / } \\
\text { emotional interdependence }\end{array}$ \\
\hline & Self-reliance orientation & Order setting control and \\
\hline & Autonomous-Separate self & autonomy orientation \\
\hline & Permissive parenting & Autonomous-related self \\
\hline $\begin{array}{l}\text { INTERPERSO } \\
\text { DISTANCE }\end{array}$ & $\stackrel{\text { NAL }}{\longleftarrow}$ apartness & Authoritative parenting \\
\hline & Hierarchical neglecting family & Family model of interdependence \\
\hline & Neglecting, indifferent orientation & Obedience orientation \\
\hline & Heteronomous-Separate self & Heteronomous-related self \\
\hline & Indolent parenting & Authoritarian parenting \\
\hline
\end{tabular}

\section{Heteronomy}

This way of presenting the differences in child upbringing and parental treatment of children surpasses to some extent the one-dimensional understanding of individualism / collectivism, complementing the descriptions of normative and relational dimensions of these opposite cultural poles. Autonomy and connection could be viewed as basic human needs, considering that all of us express the need to belong, but also to confirm our individuality and originality at the same time. It is very difficult to balance these two needs, especially if the social context in which we develop contests these two needs, or encourages fulfilment of one need at the expense of the other. Also, cultures of attachment / connection and cultures of apartness / independence affect the dominant type of family organization, division of roles, way of establishing the family hierarchy of relations, but also the self-development on the individual level.

This description of four simplified family organization types offered by Çiğdem Kağıtçıbaşı (2007) was created on the basis of inter-crossing of two key dimensions:

Activities of older generation towards autonomy (independence) and heteronomy (dependence), and

The way of building an interpersonal distance, in terms of attachment / connection (low distance) and apartness / separation (low distance).

Obviously, considering the autonomy / heteronomy and attachment / apartness, the general model of familial context and types of familial organization should be appreciated, not only in terms of the research of characteristics of a culture, but also 
of differences that occur within the scheme of causal chain between different families within the same culture, in view of numerous factors, such as: demographic features of a family, educational level, employment of parents, socioeconomic status of parents and of the family, number of children, sibling positions, presence of older generations in a joint household, encouragement to education, utilitarian values, psychologicalpedagogical values, and socioeconomic values.

The practicality of this model is reflected in the fact that changes that occur in a society and affect changes in the family and vice versa can be followed and compared from time to time. Even without referring to researches, a handful of such examples can be found in the way of raising children in our part of the world. The most evident practice which was present until a few decades ago, when all close relatives, but also neighbours could take certain "disciplinary measures" against not only their own children, but also against children of their relatives and neighbours if they found them engaging in pranks and un-allowed behaviours. Nowadays, such practice may even end up at the court. Obviously, based on the model developed by Çiğdem Kağıtçıbaşı, referring to features of a Bosnian-Herzegovinian family arising from results of our research, one can conclude that our family transformed itself from the area of heteronomy and high attachment (dependence), towards the model of distance and autonomy.

\section{Changes in lifestyle and housing conditions}

The correlation between the state of the family and state of the society is identical to the principle of communicating vessels, and it is also reflected in the violent character of living which rises against the nature around us and within ourselves. Observing the life of modern man through the prism of bioecological model, which is mostly organized in complex city centres, one can see that life increasingly goes on in nonnature. We also identify superficiality in the lack of willingness to analyse the unconscious import of violence and of non-nature in our homes that are, in most cases, claustrophobic little apartments, piled up on one another in a reinforcedconcrete unit called a building or a skyscraper. Aggressive and robust concrete complexes are places where anger and dissatisfaction are generated on everyday basis, and most people import the features of such ecological niché into themselves and transfer them to others (primarily children).

Who will persist in this robust architecture and return to it joyfully, calling it a warm home? This question is followed by questions about where children can play nowadays, streets and traffic lights they have to cross every day, and the time we are willing to dedicate to each other both in qualitative and quantitative terms, and to what extent are we able to see the violence that sneaked into our lives? Jeopardizing the nature ecosystem, humans started jeopardizing the family ecosystem as well (Alić, 2012). 
Such examples are also known in our culture, considering that a traditional human did not build settlements in places where nature could be jeopardized, or where underground waters were found. Also, a traditional house and a concept of urban and rural ghettos (in Bosnian tradition 'mahala') reflected spiritual needs and overall philosophy of human life, they were built of natural materials, as a reminder and a form of celebrating the God's gift - life. These houses also had their functional and social dimensions through which humans constantly established communication with the nature. Residential space also constitutes a kind of "regions" that divide social space in terms of time and space. Time-space convergences are adopted in this space, and they can have a significant impact on our interactions with other people. Rooms, hallways, kitchen and floors are not only physical spaces, but they mark special time zones. While we use kitchen and living room during the day, we use bedroom at night. We furnish the guest room in the spirit of 'forward' region, as a kind of a 'show' or 'presentation' of our life, while we decorate other rooms as 'back region', intimate areas reserved for daily routines (Giddens, 2007). Functional and social components of living in a traditional Bosnian house actually integrated residential regions and spatial-time convergences, defining specific interactions, movement, work, leisure and overall life of household members, but also relationship with neighbours (Čamo, 2005).

It is certain that we start developing attitude towards time and space in these residential 'regions', and that we can recognize consequences in the domain of health, building of attitudes towards others, adoption of symbolic notions of the world, but also in perceptions of own effort and responsibility, and of what constitutes happiness and fulfilment of life goals.

\section{Changes of diet habits}

The health topic which attracts increasing levels of attention relates to diet disorders and obesity, which are directly related to previous examples, and to the flood of the so-called 'fast-food', unhealthy food produced through completely 'unnatural' procedures. A series of studies point to the negative connection between weight and income in the USA: As people become wealthier, they tend to lose weight and become thinner / slenderer. In many other countries, the correlation is quite the opposite: as people become wealthier, they tend to gain weight more and more; actually, in those cultures, body weight is connected to fortune and wellbeing. Numerous studies actually found significant cultural differences in the perception of, and stereotype on satiety and obesity, and correlation with the perception of an ideal body, that can be connected to previous factors. Cogan, Bhalla, Sefa-Dedeh and Rothblum (1996, Matsumoto and Juang, 2003) asked students in Ghana, Japan and the United States about their weight, frequency of diets, social activities, perception of an ideal body, eating disorders and stereotypes of slenderness and obesity. They discovered that respondents from Ghana viewed obese bodies as more ideal in their society. 
Americans, particularly women, followed various diets in the highest percentage; they abstained from food more than others, had the largest number of registered eating and diet disorders, and expressed negative views of obesity.

Crandall and Martinez (1996, Matsumoto and Juang, 2003) obtained similar results. These researchers compared views of obesity between American and Mexican students. Results have shown that Mexican students are less concerned about own weight and acceptance by others, compared to American students. Besides, views of obesity in the USA are obviously an integral part of the social ideology which says that every person is responsible for their own life outcome. Attributes of control and responsibility were less important in predicting the views of obesity in Mexico, where the antipathy for obese people could not be correlated to any ideological framework. This stereotype of preferable physical appearance also brought an important change in our culture as well, imposing the stereotype of slenderness and the 'forever young culture'.

Although medicine nowadays frequently labels particularly vulnerable populations as 'genetically predisposed', inclination to diabetes, lactose intolerance or to alcoholism should be actually sought in the stored memories of ancestors that were developed and are still developing in interaction with the environment and traditional dietary habits. Now we know that some persons are predisposed to alcoholism by certain genes on 4th and 11th chromosomes that control the metabolism of dopamine and alcohol dehydrogenase. This is why the same amount of alcohol can cause entirely different reactions in different people; for example, native Americans and Asians (Taiwan, China, Korea, Japan) react more strongly to small doses of alcohol than Americans of European origin, and the percentage of Asians suffering from strong reactions to small alcohol doses can be five to eight times higher than among Europeans or Americans of European origin (Nabhan, 2007). It is interesting that ethnic populations that produce too many alcohol dehydrogenase enzymes in liver and tolerate fermented drinks better because of that have a long history of cultures in which they were engaged in agriculture and livestock farming, with a long tradition of alcohol production and consumption. Some nations clearly developed biological adaptations to certain plants and other food they depended on during long time periods. The domination of packaged 'fast-food' full of additives in contemporary diet and sedentary lifestyle produced generations of people who are in the worst physical shape ever in the entire history of human kind (Nabhan, 2007). This wave of changes affected the Bosnian-Herzegovinian society as well.

Our family dining tables / sofras lost their dimension, contents, meaning and charm of a kind of family spiritual meeting place and refuge a long time ago. Under the influence, particularly of Islamic teachings, special attention was paid to paying respect to the food, even to crumbs that remain after a meal (ni'met). People nowadays eat in a rush more and more, while 'passing by', swallowing large bites and 
dispersing crumbs along the way. In the context of everyday differences that can be recognized between individuals who develop within individualist and collectivist cultures, Hofstede (2005) also mentions the following facts: namely, it was found that members of individualist cultures walk faster, but also that they are more inclined to eat or drink as they move.

In the past, much more importance was attributed to what people eat, sources of food, and to who prepares the food and in what (emotional) state in this region. The Bosnian-Herzegovinian tradition knows the term 'sofra', which originates from the Arabic language, through Turkish language - sofraya buyurun, and in different meanings it refers not only to the place of having a meal, but also to a trip ( سفرات), preparation for a journey, meal for a trip, travel / passenger (سفري), journey, drive, excursion (سفرية)... It is interesting to note that the word sofra has the same root like words passenger, travel, preparation for a journey, and it makes us think about what kind of journey we are preparing for at the sofra (dining table)?

In that regard, it should be noted that our tradition included a custom for people to plant fruits by the road so that passengers-passers-by (or travellers) can use the fruit during their journey. Another term which is used with the same group of meanings, the word me'edeba (مأدبة) refers to the meaning of feast / 'sofra' (مأدبة, تأدبة), but also to well-raised, decent, polite / 'muteeddib' (متأدب) and upbringing / 'edeb' (أدبة). Morphologically, it denotes the noun referring to a place, and it can denote a place of upbringing (Alić, 2018).

As if these related terms and meanings that those terms convey want to point to the importance of a house, fireplace, 'sofra', the central place where culture is adopted and put in the function of socially-acceptable behaviour through socialization, and of talk which resulted in cultivation i.e. good upbringing in the process of enculturation and socialization (Tufekčić, 2012, 2014). This central place of upbringing developments seems to be inevitable in the process of adopting symbolic perceptions and meanings of culture, the place of production and transfer of all spiritual capitals (connected to intellectual, emotional, wilful, moral, social, spiritual... capitals).

Obviously, 'sofra' and 'me'edeba' are places where not only physiological needs of food consumption which are necessary for physical life are fulfilled, but they are also (maybe even more) places where we prepare on fundamental, intellectual, emotional and social levels for participation in the society, adoption of basic knowledge about ways to satisfy own and others' needs for safety, belonging, recognition, love, (Self) respect, and living of aesthetic and intellectual values. We wash our hands before and after 'sofra', not only for hygienic reasons, but also for the purpose of adopting values and developing awareness of the fact that the supply / 'nafaqa' (in the Islamic tradition) comes from God's mercy, and that we should not attribute it to ourselves. In one place, in his Kitab of Sayings, hafiz Husni efendi Numanagić (2018) mentions 
the example of all beautiful tastes and smells of food that come from soil which is saturated in tears of repentance of Adam and Hawa (Adam and Eve).

This is why there was always enough space at the sofras of our older generations... 'bujrun' (welcome) to everyone... and an extra cup of coffee... for an unannounced guest (in Bosnian tradition, such a visit is called: 'to come out of the blue').

Before we sit at the sofra, we participate in serving of the food, and we learn to listen to and look at each other, to educate all senses by exchanging impressions and opinions about tastes. If all meanings of 'sofra' and 'me'edeba' are satisfied, we always happily go back to that place, but we also know how to transfer that knowledge to the next generation. Therefore, we learn to adopt culture through enculturation processes. It is not by chance that the accelerated philosophy of living and the 'fast food' eating culture conquered the world by spilling over from the geographical and cultural space which is described as the world of individualistic cultures. As opposed to this concept, walking and eating at the same time will be deemed inappropriate in collectivist cultures, and a series of rituals related to the eating culture, socializing, and movement in intimate and non-intimate groups will be observed. These accelerated processes of lifestyle changes have also brought about a change in the field of understanding, both ethics and aesthetics in our daily lives.

Here, we can remember only one of the numerous rituals that characterize our culture - the coffee drinking ritual. This ritual exceeds the mere enjoyment in the favourite black and warm drink at the times of leisure - it actually depicts a fragment of a whole value system of intimation, socialization and introduction to the space of cultural standards. This is why we don't drink coffee with those who 'don't know how to drink it'.

\section{Discussion and conclusion}

Following the accelerated cultural changes, nowadays we can conclude with great certainty that a tradition which loses its symbolic contents becomes commercialized and reduced to kitsch. Societies that live separately from nature and tradition (which is specific for most Western countries nowadays) make daily decisions which carry a dark side - increase of addictions and coercions. This is a feature of living outside of traditions, and detraditionalized societies witness constant increase of coercions and addictions, and of general anxiety as a result of the undermined freedom of choice (Giddens, 2005).

Summarizing the results obtained from a series of research of the Bosnian family, we can conclude that family here is being culturally recoded, obtaining the features specific for individualist cultures, the cultures of the decreasing power distance, with short-term orientation and family distance model (Hofstede, 2001; Kağıtçıbaşı, 2007). This is a family which transforms itself from the harmony zone to mastery value orientation (Schwartz, 2007), from the area of high context to the area of low cultural 
context (Meyer, 2014), and from humane orientation towards orientation to achievements / Performance Orientation (GLOBE study, 2004). Life increasingly goes on in non-nature, and unlike traditional settlements that reflected the spiritual needs and arose from the overall human life philosophy, the contemporary housing space is an aggressive and unnatural environment where time-space convergences are adopted which are completely opposite to the traditional philosophy of life. Considering that we learn how to interact with others in that space, all social relations irresistibly remind us of the narrow environment of an apartment, the micro-prison setting which completely distanced itself from nature. Given that the 'sofra', the space and time of a join meal was a particularly important ritual of adopting the contents of culture and time-space convergence, the disappearance of the 'sofra' from our homes resulted in gradual disappearance of the symbolic contents of culture, which is why this is less and less of a ritual, and more and more becomes a routine.

\section{References}

[1] Alić, A. (2018). Kulturalni modeli odgajanja - uvod u antropologiju porodice. Sarajevo: Perfecta.

[2] Alić, A. (2012). Struktura i dinamika obiteljske kulture. Dobra knjiga.

[3] Alić, A., Cerić, H., \& Habibović, M. S. (2018a). Youth Culture Features in the Light of Preferred Role Models and Life Styles. European Journal of Social Science Education and Research, 5(2), 163-174.

[4] Alić, A., Cerić, H., \& Habibović, S. (2018b). Interdisciplinary View into Optimism and Pessimism in Emic Perspective. European Journal of Interdisciplinary Studies, 4(1), 7-17.

[5] Alić, A., \& Habibović, S. (2013). Approaching to Immigrant Families-The Scope of Transgenerational and Culture Shock Model. Procedia-Social and Behavioral Sciences, 84, 144-148.

[6] Bajramović, M. (2010). Bosanskohercegovačka metaproza. Sarajevo: Bookline.

[7] Bajramović, M. (2005). Ogledalo etike i naličje estetike. Zeničke sveske-Časopis za društvenu fenomenologiju i kulturnu dijalogiku, (02), 140-145.

[8] Barnard, A. (2000). History and Theory in Anthropology. Cambridge University Press.

[9] Beck, U., Beck-Gernsheim, E. (1995). The Normal Chaos of Love. Cambridge: Polity Press.

[10] Bronfenbrenner, U. (1997). Ekologija ljudskog razvoja. Beograd: Zavod za udžbenike i nastavna sredstva.

[11] Chaney, D. (2003). Životni stilovi. Beograd: Clio.

[12] Čamo, M. (2005). Kultura stanovanja u Sarajevu. Sarajevo: Semerkand.

[13] Doubt, K., \& Tufekčić, A. (2019). Ethnic and National Identity in BosniaHerzegovina: Kinship and Solidarity in a Polyethnic Society. Rowman \& Littlefield.

[14] Giddens, A. (2007). Sociologija. Zagreb: Globus. 
[15] Giddens, A. (2005). Odbjegli svijet. Zagreb: NakladaJesenskii Turk.

[16] Giddens, A. (2005). The Global Revolution in Family and Personal Life. In: Skolnick, A.S., Skolnick, J.H. (13th Ed.) (2005). Family in Transition. Boston: Pearson Education, Inc.

[17] Hofstede, G.H. (2005). Cultures and Organizations - Software of Mind. New York: Mc Graw Hill.

[18] Hofstede, G.H. (2001). Culture's Consequences: Comparing Values, Behaviors, Institutions and Organizations Across Nations. London: SAGE Publications, Inc.

[19] House, R.J., Hanges, P.J., Javidan, M., Dorfman, P.W., Gupta, V. (2004). Culture, Leadership and Organizations - The GLOBE Study of 62 Societies. London: SAGE Publications.

[20] Kağıtçıbaşı, Ç. (2007). Family, Self, and Human Development Across Cultures. London: Lawrence Erlbaum Associates Publishers.

[21] Kottak, C.P. (2002). Anthropology - The Exploration of Human Diversity. Boston: McGraw Hill.

[22] LeVine, R., New, R.S. (2008). Anthropology and Child Development - a CrossculturalRreader. Blackwell Publishing.

[23] Matsumoto, D., Juang, L. (2003). Culture and Psychology. Oxford: Oxford University Press.

[24] Meyer, E. (2014). The Culture Map. New York: PublicAffairs.

[25] Muftić, T. (2004). Arapsko-bosanski rječnik. Sarajevo: El-Kalem.

[26] Nabhan, G.P. (2007). Neki to vole ljuće. Zagreb: NakladaJesenskii Turk.

[27] Numanagić, H. (2018). Kazivanja dervišima. Sarajevo: Dobra knjiga.

[28] Pašalić-Kreso, P., Alić, A. (2017). Obilježja kohezivnosti i kompetentnosti porodičnog sistema u međugeneracijskom djelovanju. Sarajevo Social Science Review, Vol.VI, broj 1-2

[29] Schwartz, S.H. (2007). A Theory of Cultural Value Orientations: Explication and Applications. In: Esmer, Y., Pettersson, Th. (eds.) (2007). Measuring and Mapping Cultures: 25 Years of Comparative Value Surveys. Boston: Leiden.

[30] Segrin, C., Flora, J. (2005). Family Communication. London: Lawrence Erlbaum Associates, Publishers.

[31] Skelić, Dž., Alić, A. (2009). Postignuća učenika u kontekstu porodičnih prilika. U: Sekundarna analiza TIMSS 2007 u Bosni i Hercegovini. Sarajevo: Agencija za predškolsko, osnovno i srednje obrazovanje

[32] Steward, J.H. (1955). Theory of Culture Change: The Methodology of Multilinear Evolution. University of Illinois Press.

[33] Tufekčić, A. (2012). Osnove etnopedagogije. Dobra knjiga.

[34] Tufekčić, A. (2014). Growing up and upbringing in a traditional BosnianHerzegovinian family. Zakład Historii Edukacji Instytutu Pedagogiki Uniwersytetu Wrocławskiego.

[35] Turkyilmaz, U., Alic, A. (2012). Localism or Globalization: In Which Direction will the Bosnians go?. Insights to a Changing World Journal, (1), 26-37. 
[36] Westen, D. (1999). Psychology - Mind, Brain and Culture. Harward University: John Wiley \& Sons, Inc. 